\title{
Catholic Priesthood's Proper Matter: A Female Presbyterate?
}

\author{
Carlos M. Del Rio \\ Bradley University
}

\begin{abstract}
Conflating human gender and human sexual identity leads to fallacious conclusions that lack ontological corroborations. The Latin Rite of the Roman Catholic Church's premise regarding an all "men-male" celibate priesthood shares this conflation. An ontological examination of gender and sexuality evinces denotative distinctions among these human dimensions and deconstructs the Church's conflation that seeks for a fitting priestly representation of Jesus' maleness (sexual identity). Doubtless, not all ordained men are males, but all ordained males are men, some of whom (men and males) remain sexually active. This reality also deconstructs the universal expectation of a "celibate" priesthood. An Aristotelian examination of sacraments demonstrates the human person regardless of gender or of sexual identity is the proper matter for sacred orders. This makes the case for a female presbyterate.
\end{abstract}

Keywords: gender; sexual identity; sacramental proper matter, sacred orders; female presbyterate, hylomorphism.

\section{INTRODUCTION}

Even though gender and sexuality are not identical features of our humanity, the Roman Catholic Church, Latin Rite (the Church), conflates them in its insistence for an "all man-male celibate priesthood" (AMMCP). This AMMCP emphasis adds celibacy as a defining feature of all priests' sexuality. As a result, a preference for male priests belays the consideration of female priests. And this, although not an issue incumbent of labor fairness, is a serious concern arising from the proposition that female souls are simply unfit for holy orders (McDowell, 2013). This pejorative position on women's sexuality also presumes that women have female souls, because their coroporealities are gendered as female. At this level of metaphysics, where we recognize the human soul, it is important to revisit the constitution of the human person, and the natural components of the sacraments of the Church. Does the gendered body define the soul sexuality or does the soul sexuality define the gendered body? Or does the sexual soul only inform the gendered body? Better yet, is the body or the soul the source of sexuality? A metaphysical process is required to answer these questions. And a similar metaphysical approach is needed to revisit the Church's arguments for tradition, revelation, and the behavior made manifest in the person of the God-man Jesus that emphasize an AMMCP. Distinguishing perspectives on the nature of humanity will lead us to denote sexuality and gender as different qualities of our humanity, and to deduce the source of human sexual identity. Further, a metaphysical application of Aristotelian causality will aid us in identifying the constitutive elements of the Church's sacraments. This process will conclusively identify the proper matter of the priesthood: The human person.

\section{Origins of celibacy}

Celibacy as sexual abstention originated as a disciplinary expectation for clerics. It evolved over several events and centuries beginning in Elvira (305 CE). Celibacy was formalized in Nicaea (325 CE) forbidding priests "to live" with women who could bring them under suspicion. Eight hundred years later, the Lateran councils (1123 and $1139 \mathrm{CE}$ ) reiterated this position preventing priests from living with women of suspicion and from entering dyads with 
concubines. But for the first millennium, there never was prohibition of coitus with "acceptable" women (1 Tim. 3, New Revised International Version). In fact, conjugal relations did not officially preclude clerics from ministerial service in the Church until the Renaissance and perhaps later. For example, Simon Peter, chosen to head the paleo-Christian community, was a married man (Mk. 2: 29-31). In addition, Paul of Tarsus, whom Jesus chose to minister to the Gentiles (Gal. 2: 2, 8), advised the same paleo-Christian communities that bishops (from the Greek "episcopos," overseers of priests, who succeeded the original twelve) "be married only once" (Titus 1: 6-16).

As time progressed, however, the hierarchy of the Church argued for an emulation of Jesus in the person of all priests, presuming that Jesus was heterosexual and celibate (see alternate considerations of Jesus' sexuality in Phipps, 1996; and Driver, 1965), and insisting therefore that all priests embrace celibate life-styles to be completely dedicated to the ministry of the Church in semblance of Jesus (O'Brien, 2009). The heteronomativity of Jesus' sexuality was assumingly objectified in all priests by virtue of being gendered as men.

\section{Apostolic succession of priests}

The councils of Trent (1545 - 1563 CE) comprised the Church's counter-reformation stance that emphasized the priestly character Jesus conferred to his original followers (Matt. 26: 1730). This priestly character emerged from the institution of the Eucharist when Jesus transformed the bread and the wine into the sacramental species during that paschal meal. When Jesus spoke the consecratory words over the bread and the wine, he conferred the power to do likewise to those present at the meal, asking them to do the same in his memory (Lk. 22:19; Matt. 26:26). Arguably, this consecratory power to celebrate the Eucharistic meal was not prohibitive but rather inclusive of "all" who were present, including the women. The record does not clarify that Jesus specified this power was only intended for the "men" who were present.

The councils of Trent also added celibacy as a disciplinary expectation of all clerics, thus excluding their sexual intimacy with women, this time including women of good repute. But the two-fold emphasis of the Last Supper revealed the intermediary nature of the priestly ministry: To preside over the sacrament and to confer sacramental grace to all peoples, denoting the Eucharist as the essential telos of priesthood. Only this consecratory power was essential to priestly character, not celibacy. The record reveals the consecratory prayer was institutive of priestly orders, it did not "separate" the genders let alone the sexual identities of those present. Jesus' followers conferred this same character to their successors by laying on hands on them and praying over them (Acts 6: 6). This was the sensible sign of ordination, and this rite has been preserved to this day.

\section{Schisms within Christianity}

The Lutheran challenge against the Church's "selling" of indulgences was a correct reaction against corruptibility by the Church's hierarchy. Nevertheless, Luther's position gave rise to an unintended schism. Protestantism broke apostolic succession of priestly lineage within Christianity. On the one hand, Martin Luther's (1483-1546 CE) "95 Theses" gave rise to "Protestantism," a branch of several denominations that do not conform to the Roman pontiff. Luther's position correctly emphasized people's access to sacred scriptures' vernacular versions. On the other hand, the nascent Protestant movement broke the apostolic lines of priestly character. Swiftly, the Church responded to the nascent Reformation by reaffirming the importance of the sacramental character of priesthood and its apostolic roots in sacramental ordination (Barrat, 2006). Sacred orders ultimately subsumed presbyters and their bishops to the obedience of the Roman pontiff (Matt. 16: 18). As a result, the Protestant 
schism originating in Lutheranism precluded all subsequent Christian sects from sharing in the indelible character of priesthood. New branches of Christianity no longer shared in its legitimate dispensation of sacraments and sacramentals. Also, new Protestant ministers no longer shared in the apostolic succession that the Church has preserved. What was originally indented as a salvific sign had now become a monopoly of power that left out everyone who did not profess obedience to the Pope.

It is true that other Protestant factions emerged due to diverse reasons, but all lack the apostolic succession and the priestly character that the Church has preserved. For example, governmental loyalty as in the case of the Church of England (the Anglican Church) subjected the Anglican Church to King Henry VIII and to his successors because he was not able to obtain yet another marital annulment from the Vatican. Other schisms that broke apostolic lines of succession included the Calvinists, the Methodists, the Presbyterians, the Baptists, and so on. Still some Catholic conservatives have protested and separated from the Church after Vatican I legislated papal infallibility (1869-1870 CE). Adding to Catholic dissent, some Catholic women, claiming legitimate vocations to priesthood, have sought ordinations without Vatican approval (Kelly-Zukowski, 2005), thus, entering canonically irregular ordinations. Despite so many Protesting ramifications within Christianity, the Church continues to preserve apostolic succession of sacerdotal consecrations establishing a lineage that can be traced to the original followers of Jesus and to Jesus himself.

\section{Resulting challenges and purpose of this paper}

Adding to the preservation of apostolic succession, the Church has emphasized the selectivity of priesthood in the persons of only men-male celibates: (a) belying dialogue about married priests, in its Latin rite; (b) belying the option of a female presbyterate, and (c) negating to have the authority to change the selectivity of men. To address these positions, I argue we must use ontology to examine human nature and the distinction between gender and sexuality, ending with an identification of sacramental elements using Aristotelian causality. Also, exploring the theological aspect of human sexuality and discrepancies on papal pronouncements evince there is room for additional dialogue to effectively change the men priests preference.

\section{Human nature and human sexuality}

Two leading perspectives suggest we are either "aggregates" of more than one part; or we are "living substances" or ensouled-bodies with irreplaceable identities and life-purposes. The first view is dualism from Descartes (1596 - $1650 \mathrm{CE})$. Descartes argued we are minds trapped in bodies and mind and body are distinct substances that remain in constant friction until they are finally separated. The second view is hylomorphism from Aristotle (385 - $322 \mathrm{BCE}$ ) and Thomas Aquinas (1225 - $1274 \mathrm{CE})$. These philosophers argued apodictically the soul is the form of the body that is in turn the organic matter of the human person. Body-and-soul coexists together as a unity. Body and soul are substantial principles that complement one another, and do not have reason to exist separately. In hylomorphic terms, the mind is a power of the soul. But both perspectives recognize one aspect of our nature is invisible, whereas the body is physically visible.

There are serious consequences to each of these perspectives. However, belief in the soul does not evince a dualist philosophy. Instead, how one explains the interaction between soul and body is indicative of either dualism or hylomorphism. 
Dualism has led us to reductionism and physicalism by which we conclude our human mind is the byproduct of brain processes. And because we are wholes of many parts, we ultimately are not so much distinct from a machine and we do not necessitate biomedical ethics to preserve the dignity of our personhood. By contrast, hylomorphism or the substantial view of the organic person proposes there is a life force principle that enlivens us, and informs our organic functioning, and enables us to make sense of life in meaningful ways. In this sense, the human soul "develops in and through the body and is intimately integrated with the body" (Nichols, 2010, p. 126); forming a substantial unity.

Sexuality and gender complement human nature in expressive ways. How we explain our humanity also impacts how we view our gender and our sexuality both in ontological and in theological terms. Dualism and hylomorphism view these concepts differently.

Dualism allows for a biological (material) emphasis of personhood and this leads to reductive physicalism that argues the mind is the result of physical processes (Murphy, 1998). In this sense, one's identity is determined chromosomally. One's genetic information determines one's development and one's personality, and character. One's sexuality is a matter of choice whether it matches one's genitals or not. And one's gender is biologically based and thus dimorphic by genitalia. The mind is the result of molecules interacting in neural pathways and systems. When these processes are interrupted, so is the existence of the mind. If one lacks cognitive faculties, it is because the brain is affected in some fashion. And if the mind is not manifested through intelligible behavior (such as speech or coherent verbal patterns of discourse), the notion of personhood is not defensible.

By contrast, hylomosphism insists that body and soul come together telically. Neither body nor soul have a reason to exist without the other, they both form a unity that is not replaceable: a human person. The soul informs the body and its organic functions (Aristotle, 1996). And the body makes the soul manifest in tangible ways. The body and the soul make up a living human person. Mental or cognitive functions are not the only evidence that a person exists. Every organic function from within manifests that a person is alive. One's gender may follow a genital pattern, but one's sexuality is beyond mere genitalia. Gender is a social construction. One's sexuality is one's persistent sense of identity toward intimacy- and reproduction-related functions (including parenting and caring).

In 21st century, we no longer consider only two phenotypic (woman and man) corporealities to be the human sexual norm, because then intersex corporealities would be "abnormal" and not simply other phenotypic sexualities (Paris, 2011). So, for our purposes, gender is indeed a social convention (Lorber, 1994), a cultural expectation of what human sexuality (and sexual behavior) may look like based on corporeality (of women and of men). Gender is learned from interaction with others, and it is based on the phenomenal perception of dimorphic corporeal configurations. As such, gender leads to socially acceptable sexual behaviors, which shape a person's expression of self as either men or women.

Unfortunately, gender expectations are built into major social institutions such as religion, economy, politics, and family relations; affecting individual perception and manifestation of one's self. As gender expectations become imbedded in societies, they become pervasive and very difficult to change. This seems to be the case with the Church's public position about nonheterosexual persons-yet a growing number of ordained priests and bishops are not heterosexual (Blauner, 1991). This is not simply anecdotal; for example, many ordained men in Vatican City State are not heterosexual. 
Albeit it is tempting to conclude that sexuality (femaleness and maleness) are more acceptable categories from birth, we face the same problem as above with dimorphism. It gets more complicated if we were to claim these sexuality terms are only "cultural constructions" as some authors have suggested (e.g., Paris, 2011, p. 31). Instead, the sense of one's sexual identity is more ubiquitous than even one's corporeality (Irvine, 1990). Sexuality influences human conduct. Persons know instinctively and distinctly who they are sexually over and beyond their experiences, feelings, choices, ages, and many other facets of humanly gendered experience. One's sexual identity is one's self-identification as male, female, homosexual, bi-sexual, transsexual, or any other manifestation of one's sexuality (Hyde \& Delamater, 2011). Thus, maleness and femaleness are heteronormative, whereas man and woman are gendered terms.

So where does sexuality come from? Human beings do not come from acorns in the natural order. Human persons beget human persons by the chromosomal sharing of maleness and femaleness regardless of reproductive means or technologies. And from Aristotelian and Thomist perspectives, human creatures are substances. Persons are soul-and-body unities, living substances, not aggregates, as Descartes and other dualists have erroneously suggested (Nichols, 2010). "The soul makes the body a substance and an independently existing thing" that is also sexual naturally (Nichols, 2010, p. 67).

The Aristotelian position that recognizes a soul inhabiting a body and a body expressing a soul is by no means a suggestion of a Platonic or Cartesian view of human composition. Instead, acknowledging two principles of existence for a single living organism is well within the confines of logic and it only evinces the substance nature of every human person. Further, the recognition of form-and-matter as the composition of one single human substance helps us understand one's sexual identity. In this sense, bodily configuration (out of which a person comes to be) has an individual sexuality (an account of what a person is to become sexually). And, the soul conveys that very sexual identity whether the bodily configuration matches it or not.

\section{Soul is the source of sexual identity}

The human soul is "an organizing principle that configures the matter of which it is a form" (Nichols, 2010, p. 126). In this sense, the human soul is the "ever" informing source of cohesion that provides each person with personal identity that is sexual in nature. And this soul originates in God. As such, human sexual identity originates in the human soul regardless of gender-like corporeality (Benagiano \& Mori, 2007).

God is the origin of all existing nature. And nature qua nature encompasses the human soul. God allows each soul to come into existence whenever a new person is created in human history. Ancient myths have also identified deities as the source of humanity (see for example O'Brien \& Major, 1982). Furthermore, it follows it is God's creative impulse that generates human souls, and souls inform the nature and purpose of human persons to be rational, intelligent, and sexual human beings (Benagiano \& Mori, 2007). By consequence, human sexuality is first willed by God. It becomes available in the human realm through each person whether male or female, allowing for any other types of natural sexual identities augmenting the allegorical dimorphism in Genesis 1:27.

Sexuality is such a deep and powerful force that enables humans to experience life in unexplainable and profound ways. This self-evident value of sexuality is what makes it intrinsically related to individuals' nature. Sexuality is also communal. It enables us to find intimacy with others and to propagate our species. Sexuality is also pleasurable, and it helps 
make tangible human commitment and selectivity among partners. These sexual attributes also remind us of our need for greater intimacy with what is divine and numinous. And this proclivity toward unity with one's partner and with what is divine is sexuality's outward manifestation. At this level of communion we wish only what is good for those with whom we are nakedly intimate. These personal and relational aspects of human sexuality are thus telically theological.

\section{Priests of the New Covenant: Beyond gender}

The New Covenant comprises the life, ministry, and resurrection of Jesus. His earthly existence took place in a Semitic, patriarchal society that devalued women (Greeley, 2007; Greeley, 2004; Reumann, 1966; Steinfels, 2003). Perhaps and doubtless for this reason Jesus made the effort to relate to women, to speak with women, to share meals with women, to spend time with women, and to covey to women unequivocal messages about his identity and his ministry (Del Rio, 2012; Thiemann, 1987). These overt behaviors of Jesus evinced a willingness to establish equality between sexes beyond gender-based expectations of conduct.

We owe deference to women. Women are not simply companions of men. Women have an immense ability to be genuine and kind, more so than men. They are equipped to bear life and to sustain life in ways that are meaningful and encompassing, not simply because they have a uterus, but also because their emotional quotients may be higher than men's. Their hormonal make up helps accomplish these functions. Jesus was aware of women's dignity and his actions willfully incorporated women's contributions to his ministry in this New Covenantal context. More important, without women Jesus could not have taken on human flesh or learned about fairness and traditions. We must reflect seriously about the purpose and the role of Jesus' interactions with women and on the roles that women played in his life from birth, to death, to burial, to resurrection.

We know that women followed Jesus (Lk. 8: 1-3), they touched him, they cleansed him, and they cared for his needs, while ministering to others (Lk. 10); and most important women were also with Jesus at the foot of the cross, and at his empty tomb. Making himself available to women manifested Jesus' objective inclusion of women in his life and ministry. These behaviors also conveyed Jesus' deference to women against his own cultural and religious expectations.

What do we make of these outward manifestations that Jesus willingly expressed in public settings? Are these willful choices not the result of God's Spirit moving Jesus to act as he did? Doubtless some of the functions women performed were indeed sacerdotal. Was this a prototype for priests of the New Covenant, one that included all sexes?

\section{The Church's position}

Regardless of early accounts of the possible ministry of women in Christianity, and of married men serving as bishops and priests (1 Tim. 3: 2), as time evolved, the Church has moved away from considering either married men or women in ministry. The Church's insistence on only an "all" man-male celibate priesthood (AMMCP) has become ethnocentric. It has become embedded in the very fabric of its beliefs and it is difficult to be reconsidered, but not impossible to be modified. This perspective is not a denigration of non-heterosexual men serving as priests, but a dispute against misogynistic position of the Church relative to sacred orders (priesthood).

The historical preference for all men-priests originated in Platonic and Manichean philosophies of human nature that conceptualized females to be less than males in human terms. Other non- 
Christian traditions embrace celibacy as a form of asceticism to abstain from sexual activity (O'Brien, 2009) but also to avoid contact with women and worldly attachments (e.g., Pietkiewicz \& Bachryj, 2014). Ancient dualistic philosophies from Pythagoras and Plato considered females were passive during coitus and thus they were only receptacles of the seed of life that males conferred (Allen, 1985). In addition, because women are physically more attractive than men, they were labeled as sources of temptation. And because women were physically endowed to bear new life, they were considered weak, and they became the responsibility of men (Heid, 2001).

Preference for all men-priests was solidified at every instance a canonical decision was made toward celibacy. Eventually, Inter insigniores (1976) and Ordinatio sacerdotalis (1994) comprised the Church's most recent attempts to end the dialogue about the reception of women into the priesthood. But neither of these documents contains dogmatic pronouncements or papal infallibility. Thus, there is hope for continued consideration such as the dialogue this paper seeks to instigate.

\section{The sexual denigration of females}

The Church's main themes for an AMMCP have included (a) women's natural subjugation to men, (b) God's preferential historical behavior for men-priests, (c) Jesus' choice of twelve "men," (d) the Church's historical choosing of only "men" to the priesthood, (e) the axiom in persona Christi by which "men" represent Jesus' "maleness" best; and (f) the Church's claim to lack authority to change Jesus' will about male priesthood (see Table 1).

The cogency for themes includes "historical tradition" and "divine revelation" as sources of authority for the Church's "magisterium." But this magisterium belongs only to the hierarchy. And this hierarchy has argued for a seemingly unalterable preference for an AMMCP. So, beyond celibacy, it becomes an issue of gendered-sexual preference of men over women.

What makes this gender-sex conflation so difficult to address is the fact that the Church's hierarchy preserves, interprets, and claims to be the sole repository of the authority to teach what everyone must follow. This argument is an institutional monopoly of power that lacks internal consistency. For example, several events in history contradict this stance. To meet the events of the times, there have been contradictions in papal positions regarding social justice issues contained in Rerum novarum (1891) and Laborem exercens (1981). What is evident is the Church has made the effort to match the changing needs of society.

By and large, the Church's teaching on revelation emerges from the promise Jesus made to send the Spirit to guide his family on earth (Jn. 14:16). The Spirit's revelation takes place in the human conscience. This guidance comes from God's Spirit (read Paul VI, 1965), and its content is not exclusive of the hierarchy. Furthermore, the Church qua community is the people of God not only the hierarchy. This reconsideration requires a closer look at the in persona Christi theological axiom relative to the sexuality of the priest beyond his gender; furthermore, this reconsideration also requires an Aristotelian method of causality to better determine the proper matter of this sacrament (see Table 2). 
Table 1. Catholic arguments for an all men-male celibate priesthood

\begin{tabular}{|c|c|c|c|c|}
\hline Argument & $\begin{array}{l}\text { Scriptural } \\
\text { Source }\end{array}$ & $\begin{array}{l}\text { Vatican } \\
\text { Position/Scholar } \\
\text { Sources }\end{array}$ & $\begin{array}{l}\text { Factual aspects } \text { of } \\
\text { sexuality and gender } \text { in } \\
\text { ordained men. }\end{array}$ & Implications. \\
\hline $\begin{array}{l}\text { Women's } \\
\text { Natural } \\
\text { Subjugation } \\
\text { to Men }\end{array}$ & $\begin{array}{l}\text { 1 Cor. } 14: 34 \\
\text { and } 1 \mathrm{Tim} . \\
2: 12\end{array}$ & $\begin{array}{l}\text { Omitted since } \\
\text { Vatican II }\end{array}$ & $\begin{array}{l}\text { Denigration of women as } \\
\text { unfit to represent Jesus' } \\
\text { maleness. }\end{array}$ & $\begin{array}{l}\text { Sexual defines humanity. } \\
\text { In Jesus there are no } \\
\text { sexual } \\
\text { distinctions. }\end{array}$ \\
\hline $\begin{array}{l}\text { God's } \\
\text { Preferential } \\
\text { Historical } \\
\text { Behavior for } \\
\text { Males }\end{array}$ & $\begin{array}{l}\text { Lev. 21: 4, } \\
\text { 7, 13-14 } \\
\text { Lev. 8: 1- } \\
\text { 39, Ex. 29: } \\
\text { 1-37 } \\
\text { Ex. 22: 29- } \\
30\end{array}$ & $\begin{array}{l}\text { Inter Insigniores } \\
(1976), \quad \text { and } \\
\text { Ordinatio } \\
\text { Sacerdotalis } \\
(1994)\end{array}$ & $\begin{array}{l}\text { Males (presumably } \\
\text { heterosexual) were married } \\
\text { men in the Old Covenant, } \\
\text { and also in the New } \\
\text { Covenant. }\end{array}$ & $\begin{array}{ll}\text { Deconstruction } & \text { of } \\
\text { celibacy expectations. }\end{array}$ \\
\hline $\begin{array}{l}\text { Jesus' Choice } \\
\text { of } \\
\text { Original the } \\
\text { Twelve } \\
\text { "Men" }\end{array}$ & $\begin{array}{l}\text { Mk. 2: 29- } \\
31 \\
\text { Gal. 2: } 2,8 \\
\text { Tit. 1: 6-16 }\end{array}$ & $\begin{array}{l}\text { Inter Insigniores } \\
(1976), \quad \text { and } \\
\text { Ordinatio } \\
\text { Sacerdotalis } \\
(1994)\end{array}$ & $\begin{array}{l}\text { Not all chosen men were } \\
\text { unmarried, and the paleo- } \\
\text { Christian praxis did not } \\
\text { require celibacy for } \\
\text { priesthood. }\end{array}$ & $\begin{array}{l}\text { Deconstruction } \\
\text { celibacy expectations. }\end{array}$ \\
\hline $\begin{array}{l}\text { Church's } \\
\text { Historical } \\
\text { Choosing of } \\
\text { Only "Men" } \\
\text { to Priesthood }\end{array}$ & $\begin{array}{l}\text { Church's } \\
\text { traditional } \\
\text { behavior } \\
\text { including } \\
\text { the Eastern } \\
\text { Church }\end{array}$ & $\begin{array}{l}\text { Inter Insigniores } \\
(1976), \quad \text { and } \\
\text { Ordinatio } \\
\text { Sacerdotalis } \\
(1994)\end{array}$ & $\begin{array}{l}\text { Not all ordained men are } \\
\text { males, but all ordained } \\
\text { males are men; and some } \\
\text { ordained men are not } \\
\text { celibate. }\end{array}$ & $\begin{array}{l}\text { Deconstruction } \\
\text { celibacy expectations. }\end{array}$ \\
\hline $\begin{array}{l}\text { In Persona } \\
\text { Christi by } \\
\text { which "Men" } \\
\text { Represent } \\
\text { Jesus' } \\
\text { "Maleness" } \\
\text { Best }\end{array}$ & $\begin{array}{l}\text { Summa } \\
\text { Theologica } \\
\text { 3, q. 78, a. } \\
\text { 5c. }\end{array}$ & $\begin{array}{l}\text { Butler, S. (1995). } \\
\text { Quaestio Disputata } \\
\text { "In Persona } \\
\text { Christi:" } \\
\text { Response to } \\
\text { Dennis M. Ferrara, } \\
\text { Theological } \\
\text { Studies, 55, 61-80. }\end{array}$ & $\begin{array}{l}\text { The Church has ordained } \\
\text { homosexual men but they } \\
\text { remain unable to represent } \\
\text { Jesus' sexual identity } \\
\text { (maleness) best. }\end{array}$ & $\begin{array}{l}\text { Gender and sexual } \\
\text { identity are conflated in } \\
\text { Church's praxis. These } \\
\text { aspects of humanity are } \\
\text { distinct. Homosexual } \\
\text { men cannot represent } \\
\text { Jesus' maleness best, and } \\
\text { sexually active priests } \\
\text { cannot represent Jesus' } \\
\text { presumed celibate status. }\end{array}$ \\
\hline $\begin{array}{l}\text { Church's } \\
\text { Lack } \\
\text { Authority to } \\
\text { Change } \\
\text { Jesus' Will }\end{array}$ & $\begin{array}{l}\text { Church's } \\
\text { claim }\end{array}$ & $\begin{array}{l}\text { Insigniores (1976), } \\
\text { and Ordinatio } \\
\text { Sacerdotalis } \\
(1994)\end{array}$ & $\begin{array}{l}\text { Jesus' historical choice of } \\
\text { the original twelve men } \\
\text { warrants an anthropological } \\
\text { examination of } 1^{\text {st }} \text { century } \\
\text { gender politics. } \\
\text { Nevertheless, if sacerdos } \\
\text { delivers Jesus to the world, } \\
\text { so did his Mother when she } \\
\text { gave birth to the Word- } \\
\text { incarnate (ab persona } \\
\text { Christi), and Mary } \\
\text { Magdalene completed the } \\
\text { Kerygma by delivering the } \\
\text { resurrection news to the } \\
\text { original eleven men. No } \\
\text { man was chosen, but only } \\
\text { women for these pivotal } \\
\text { actions that cemented the } \\
\text { New Covenant. }\end{array}$ & $\begin{array}{l}\text { The Church cannot know } \\
\text { fully Jesus' will other } \\
\text { than accept a de facto } \\
\text { Roman milieu and } \\
\text { Hebrew perception of } \\
\text { women. This context } \\
\text { warrants an examination } \\
\text { of the proper matter or } \\
\text { recipient of priesthood } \\
\text { (see Table 1). The church } \\
\text { does have the authority to } \\
\text { change the preference of } \\
\text { only men to the } \\
\text { priesthood. Additional } \\
\text { dialogue is warranted. } \\
\text { Both human sexes } \\
\text { represent besus' } \\
\text { humanity best. }\end{array}$ \\
\hline
\end{tabular}




\section{The Pauline perspectives about women}

The original followers of Jesus wished to preserve their Jewish kosher but Paul forcefully insisted that circumcision, for example, was not required to be a follower of Jesus. Paul did not accept the Old Covenant claim that circumcision should mark the chosen people of God; neither should kosher, nor worship at the/any temple. These were serious challenges to make in a first century animistic culture. Arguing against circumcision, for instance, was comparable perhaps to arguing today for a female presbyterate.

One of the duplicitous issues in Pauline theology was the subjugation of women when partaking in the liturgies (1 Cor. 14:34; 1 Tim. 2:12). Yet, some of Paul's companions, ministers, and benefactors were women (Rom. 16). Many possible explanations could illumine what Paul intended to say, but what is certain is that he was, on the one hand, conflicted with inclusion rites for men; and on the other hand, he accepted the contemporary subjugation of women that permeated the Greco-Roman era in which he wrote. These Pauline writings preserved the controversial cultural inequality between the sexes in first century societies.

We could also presume Paul was only endorsing what was culturally acceptable. But this endorsement of his cultural conventions has certainly clouded the Church's perception of women over two millennia. Nevertheless, at another level Paul emphatically argued that "neither male nor female" distinctions must come between persons who follow Jesus (Gal. 3: 28). That is, there is no room in Christian identity for sexual denigration of persons.

Sadly, some Church hierarchy members still embrace the subjugation of women to men. Some systemic theologians even suggest that a female soul is perhaps not as complete as a male soul to carry out priestly tasks (see for example McDowell, 2013). Their argument adumbrates that ordaining a female soul, which is considered unfit by sexual identity, would be sacramentally futile as if ordaining a heretic, whose soul is unfit to receive the character of priesthood.

\section{God's preference for males but not celibacy}

Despite records of female priestesses, the Old Testament concurred with Babylonian, Etruscan, Egyptian, and other polytheistic religions that emphasized male priesthood. There are preferential guidelines in the Pentateuch (e.g., Lev. 8) for males' and first-born males' dedication to serving the nameless God of the Jewish people. Abraham, for example, was called to intimacy with a God whom he did not see, whose name he could never pronounce, and whom he did not understand much of the time. Yet, because Abraham opened his heart and trusted this God, he in return received a promised homeland, a chosen people's status, and a significant progeny from coitus with both a barren a wife and a slave woman. Naked trust in God propitiated a Covenant with Abraham.

God's Covenant was accomplished through cooperation of the sexes. On the one hand, males mediated human relations with the divine. On the other hand, God's promise of proliferation was achieved through females. And, mothers, yet mediated in the temple by men, transmitted Jewish identity to Abraham's descendants.

This Covenant between God and his people allowed for reconciliation when humans diverted from God. To atone for human errors or moral wrongs priests sacrificed animals. Sacrifices of unblemished animals in cultual rites evolved over three millennia. But ritual sacrifices beg the question whether God needed to be appeased for human transgressions or sins. We know however that God prefers mercy in the human heart and not sacrifices. But the role of sacrificer was the role of the priest, as a sort of human bridge between God and humanity. Procreation 
through sexual activity was not considered a sinful feature of priests. Instead, sexual communion was crucial for God's plan to achieve human proliferation.

Propagation of the human species and proliferation of Abraham's descendants were synonymous through sexual activity. This sexual telos also made God's plan tangible. For example, Levite priests were not forbidden from coitus even with more than one woman. Their first-born males were also priests and this preserved the sacrificial role for the atonement of sins (Num. 8). Yet, the deeper purpose of priesthood was worshiping God and not merely offering sacrifices that could not properly obtain conversion of the human heart. Over time, respect and reverence for this priestly caste evolved in the Semitic tradition. This status has been preserved to current times even when priests have not earned people's respect.

\section{Did Jesus choose only men?}

What we know about Jesus comes mainly from the Scriptures and from the Apocrypha. Our sources also include the Patristic literature both Latin and Greek, and other early accounts of whom Jesus was, what he said, and what he did. Still these sources include the martyrs' testimonies. Martyrs spoke about the friend they knew and they were willing to die to testify to his message and to his works.

Had God chosen to take on human flesh as a woman in the Semitic, patristic, sexist, and misogynistic society in which Jesus was born, it is possible that God would have made a profound mistake of tremendous implications. Jesus as a woman would have never achieved his mission. But God does not make mistakes (Mal. 3:6; Isa. 46:9-10). Jesus chose to take on human flesh in the proper time and place. This was a manifestation of the Spirit's guidance in the person of Jesus from his gestation to his crucifixion to his resurrection to his ascension.

In his society, Jesus learned primarily from Mary. His mother-and-a-woman taught Jesus about kindness, about justice, and about traditions early in his life. Jesus shared Mary's flesh, and Mary's blood. Jesus embodied Mary's chromosomal makeup. She tended to his needs, wiped away his tears, put him to bed, and probably told him stories. Mary also taught Jesus about virtues and vices, and about good and bad behavior according to their conventions. And, Jesus learned from Mary many other behavioral manifestations within his cultural milieu. This female's motherhood shaped the identity of the male who was to become the most important personage in the history of humanity. Femaleness shaped maleness. Mary is the mother of God-

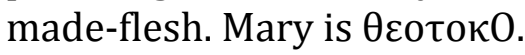

When Jesus' ministry began, he took on a zealous attitude and called on men he met on his journeys (Aslan, 2013). We read Jesus had a commanding attitude and an appearance that spoke for itself in a prophetic manner, though he was homeless and dispossessed. In fact, we read that Jesus was practically a vagrant and someone who enjoyed wine, and parties, and the company of those rejected by his society (Lk. 33-44). He chose to break prohibitions in order to draw attention to the dignity of every human person beyond the framework of law (Mk. 2:27). The record tells us how Jesus cared deeply for people. He looked at everyone as if he or she were the only person around. His stare was convincing and enticing to embrace a deeper sense of intimacy with God. Jesus' words, actions, and presence had a prophetic, regal, and sacerdotal gravitas.

The men Jesus called left behind everything to follow him. They followed his ideals, and his dreams. But their women and families also followed them. These men were not stupid to follow another pseudo-messiah to be killed by the occupying Romans. They knew intuitively that Jesus spoke with veracity of a kingdom that was transforming and meaningful beyond human 
affairs (see Armstrong, 2001). And proof of Jesus' transparency is that he did not have hidden agendas or a desire for earthly power or possessions. Instead, Jesus simply cared for the welfare of all sexed persons. The Spirit of God imbued Jesus' words and actions with meaningful and transforming power (Matt. 10:16). His Spirit provided Jesus with ways to tell stories that made sense to those who followed and listened to him.

Jesus also modeled deference to women. In one instance, Jesus chose a woman from Samaria. This Samaritan woman was not above reproach, and was not considered worthy of anything by Jesus' tribe. Nonetheless, Jesus chose this unmarried, sexually active woman to reveal to her who he truly was. He also sent her to tell her people about him (Del Rio, 2012; Jn. 4:25-26). This woman was divorced by men several times, according to rabbinic law. She cohabited with a man with whom she was sexually active and not married. Jesus' men followers were shocked. Yet, they accepted his behavior and its message. They recorded it. We learn from the details of this story that Jesus planned it well. Jesus waited alone at the well for this woman (Jn. 4:4-6) to appear at the noon hour. The gospel writers knew these details were important when recounting this story.

Jesus never judged women's sexuality. Instead, he pointed out men's co-participation in sexual activities (Jn. 8:7). Jesus did not condemn or ridicule either women or men for being sexually active (Jn. 4:18). Jesus understood the covenantal value of sexuality and its purpose in human affairs. He respected the choice to enter into private relationship with another. His ability to accept people, as they were, was itself redeeming and transformative (Girzone, 1994).

Genital activities have been regulated and condemned by many religions over the course of history (e.g., Duran, 1993). Yet, without coitus in the first century or at any point in the history of our species, no human life on earth would have prevailed to this day. The Covenant between God and Abraham also would have never been realized.

Mounting evidence has shown how sexual we humans are. We think and daydream about sex constantly and everything we do expresses our embodied sexuality (see Fisher, Moore, \& Pittenger, 2012). Thinking and acting sexually is ingrained in our identities and in our species. Yet, we conform to social and religious mores lest we be judged. Embracing heteronormativity views Jesus as a heterosexual, yet, celibate man (Phipps, 1996). But this celibate perspective was in utter contrast to Jesus' time and culture. As a first century Jewish man, Jesus was compelled to marry. And as a fully human person, Jesus experienced sexual attractions naturally.

But Jesus also was aware of the patterns that regulated sexual transactions between men and women. With this knowledge, Jesus conveyed a message that was beyond the conventions of his time. And he chose to challenge the traditions of his culture. For example, Jesus did not condemn any one's sexuality (Jn. 8: 11), nor was he too concerned with life's vicissitudes or personal privations. He was not interested in linking human suffering to sin (Jn. 9: 3). Instead, his macaristic attitude manifested a predilection for a simple life cemented on silent reflection, fasting, and prayer that led to an intimacy with God. It is at this level of intimacy with God that the human conscience is found. And conscience is where divine revelation takes place (Lk. 6: 12; Mk. 9: 29; Matt. 17: 21; Paul VI, 1965). Here we discover our sexuality leads us to communion with another and with God.

Part of Jesus' message also included instructions for new ministry that met people's spiritual needs and brought a profound sense of justice to the priesthood. Jesus was very clear when he 
told his followers to give freely the gifts they had freely received (Matt. 10:5-8). These gifts do not belong to them. The sacraments belong to all who are invited to the banquet table, the Eucharist. Priests are not only expected to prepare this meal, but are also expected to serve this meal to all who come forth to receive it. This includes all who have been invited and pulled forth by the inspiration of the Holy Spirit. As servants, priests are not to turn away anyone who has been moved or invited to partake in this meal.

Jesus also worked very hard to establish equality between human sexes. To bring women to an equal level to their contemporary men, Jesus made every effort to relate to women, to speak with them, to spend time with them, and to covey to them unequivocal messages about his identity (Jn. 4). Jesus exalted women against his contemporary religious expectations. We also know that Jesus allowed women to follow him and to care for others (Lk. 10: 1; Mk. 15: 41). These women spoke about Jesus to others, and these others believed in him because of women's testimony.

Women were among the men Jesus called (Jn. 15: 16) yet these women remain nameless. Perhaps the early authors did not name these women because they wanted to protect their privacy and ensure their safety in tumultuous times. The men and women who followed Jesus, listened to him, and learned from him not only about his ability to do supernatural things, but also about his genuine care for people. Their task was to live the way Jesus lived.

After Jesus was unfairly tried and executed (see Cohn, 1963), he came back as he said he would. The record tells us he visited his friends, he ate with them, and he showed them his wounds (Jn. 20:20). And, when he came into their midst and blew the Spirit of God unto all present, he gave them power to forgive sins (Jn. 20-22). Doubtless women were also present. Again, Jesus' power to forgive sins was not exclusive by gender or sexual identities. Just as they were first at the empty tomb, just the same they were at the table during his last supper, and at the foot of the cross, women were present when the completion of the kerygma was accomplished.

So, through his actions, Jesus' followers learned his message of love, his acceptance of our humanity, just as we are, and where we are in our life-journeys. But this acceptance included women whom Jesus commanded to go and tell the good news (Lk. 10: 1-23). These are essential aspects of priestly ministry. And first century believers only spoke sincerely about the man they knew. They were not interested in hierarchies. These layers of ministry developed later in the history of the Church (Chadwick, 1993).

\section{“Men” represent Jesus' "maleness" best?}

Aquinas apodictically explained how the transformation of substances takes place at the altar during the Eucharist (e.g., Council of Trent, 13th session ending 11 October 1551, see O'Malley, 2013). This power to effect transubstantiation has been handed down through the rite of ordination (see Barrat, 2006). By and large, Aquinas also suggested "a sacramental sign should bear a natural resemblance to the reality signified" (Butler, 1995, p. 68). However, there are some challenges to the representation of Jesus at the altar. If Jesus was indeed a man and a male and heterosexual, and our priests must act in Persona Christi, this requires not only of sufficiency but also of necessity that our priests be men-males, and not non-heterosexuals because only men who are males and heterosexuals may represent the person of Jesus best. But Jesus' literal humanity encompasses all human sexes by virtue of essential aspects of human beings. 
The Church's current position emphasizes that: (a) only men can be priests, and (conjointly) only males can be priests (this joint premise assumes their heterosexual identities) [but not all men priests are male priests]; (b) yet, only men-male priests may represent Jesus best [this position reflects the Pauline submission of women to men, this contradicts the Pauline injunction to avoid sexed distinctions because these are not acceptable in Jesus, Gal. 3:28]; and (c) all priests must be celibate, [but not all priests are celibate]. At least five challenges emerge from these considerations.

First, the Church conflates two human dimensions that are not one and the same from a strictly ontological (what is real) perspective: Gender is not sexuality.

Second, the insistence for an all men-male, celibate priesthood lacks universal corroboration in the actual world. Some men priests are not males, and some men priest males do not consider themselves as men (Blauner, 1991); and some men-male priests are not celibate but they are sexually active (Hoenkamp-Bisschops, 1992). Only some men priests are male (if by male we mean heterosexual), and this is contrary to the Church's universal expectation of male heterosexuality in priests. Their non-heterosexual identities and their sexual activities (in private, including the sexual relationships of those who are heterosexual) render the Church's arguments for celibacy false and invalid.

Third, not all priests are celibate (Hoenkamp-Bisschops, 1992). Only some priests are celibate. And these sexual aberrations to the Church's expectations include bishops, archbishops, and cardinals. These contradictions present serious difficulties to the Church's legislation on celibacy. Again, these realities render the Church's argument unsound and irrefutably invalid; the Church's universal insistence for celibacy finds no absolute corroboration in the world we inhabit.

Fourth, at issue, remains the sacramental representation of Christ's maleness by a human that is a man and that is an ordained priest. Sacraments are liturgical symbols of theological import because they convey divine grace [i.e., God's own life] to human beings who celebrate them ritually (Ratzinger, 1994), but here the Church insists on sacraments as signs, or a congruent and identical representation of a man-male to stand in the person of Jesus to function identically as Jesus even by representation.

There are also two aspects to the co-participatory priesthood of Jesus. On the one hand, a priest acting in persona Christi delivers Jesus to humanity. But the first person that effectively delivered Jesus to humanity was a female, Mary, his mother, acting ab persona Christi. Mary and Jesus shared the same flesh and blood and humanity. Mary's humanity made possible for God to take on human flesh.

On the other hand, Jesus is the supreme priest because he offered himself for all humanity. He was the sacrifice and the sacrificer. Thus, the sacrament of priesthood culminates on the celebration of the Eucharist. From this sacramental conjunction, Priesthood-Eucharist, the Church has argued for a men-male priesthood that might represent Jesus-male best.

Fifth, priests only act apophatically as representing one by another. Here, the congruence of identity is lacking because the God-man Jesus can never be fully represented by a human being let alone by a man who may or may not be male (Ferrara, 1994a; Ferrara, 1994b). Nevertheless, because Jesus took on human nature, it is that any human being can represent him best regardless of gender or sexual identity. Jesus became a member of Homo sapiens 
species to raise this species to a level of intimacy with God. Humanity meets divinity in the person of Jesus, in whom divinity also meets humanity.

"the function of [priestly] hierarchy in its deepest essence is not to stand vicariously as lord in the place of Christ, but to call the church over and over again into the presence of him who alone is Lord until he comes again. And this, to add the pertinent implication, can be done as easily by a man as by a woman" [my emphasis] (Ferrara, 1994a, pp. 223-224).

Gender must not limit the sexual identity of the person standing at the altar, presiding over the Eucharist. Conclusively a priest is a minister (i.e., a servant) for the community but not a leader of such community in the strict sense of the term. To consecrate the Eucharist dimorphic gender distinctions do not matter. The sexual identity of the human person only makes manifest the creatural aspect of the minister who represents Jesus at the altar, and this includes comprehensibly both men and women regardless of sexual identity whether heterosexual or non-heterosexual because Jesus chose to share in this same human nature fully and without reservations (see Table 2).

Table 2. Sacraments: their forms and matters.

\begin{tabular}{|c|c|c|c|c|c|}
\hline Sacrament & Form & Matter & Agent & & Purpose \\
\hline Baptism & $\begin{array}{l}\text { Trinitarian } \\
\text { formula }\end{array}$ & Liquid & $\begin{array}{l}\text { Any } \\
\text { Person }\end{array}$ & Human & $\begin{array}{l}\text { Re-generation into the life of } \\
\text { grace }\end{array}$ \\
\hline Confirmation & $\begin{array}{l}\text { Consecratory } \\
\text { Prayer }\end{array}$ & $\begin{array}{l}\text { Consecrated } \\
\text { Olive Oil (Holy } \\
\text { Chrism) }\end{array}$ & $\begin{array}{l}\text { Bishop } \\
\text { delegate }\end{array}$ & or & $\begin{array}{l}\text { Re-affirmation of life of grace } \\
\text { and conferral of spiritual gifts }\end{array}$ \\
\hline Euch & $\begin{array}{l}\text { Anaphorae } \\
\text { Words } \\
\text { Institution }\end{array}$ & $\begin{array}{l}\text { Unleavened } \\
\text { Bread and Red } \\
\text { Wine }\end{array}$ & $\begin{array}{l}\text { Bishops } \\
\text { priests }\end{array}$ & and & Sharing in the paschal meal \\
\hline Priesthood & $\begin{array}{l}\text { Laying on of } \\
\text { hands }\end{array}$ & Human person & Bishop & & $\begin{array}{l}\text { Sharing into ministerial } \\
\text { priesthood }\end{array}$ \\
\hline Marriage & Spoken Vows & $\begin{array}{l}\text { Public/ private } \\
\text { commitment }\end{array}$ & Couple & & Establishing a sacred covenant \\
\hline Penance & Absolution & Contrition & iitent & and & ess of sins \\
\hline Extreme Unction & $\begin{array}{l}\text { Prayer for the } \\
\text { sick }\end{array}$ & $\begin{array}{l}\text { Consecrated } \\
\text { Olive Oil (Oil } \\
\text { of the Sick) }\end{array}$ & $\begin{array}{l}\text { Priest } \\
\text { delegate }\end{array}$ & or & $\begin{array}{l}\text { Forgiveness of sings and } \\
\text { healing }\end{array}$ \\
\hline
\end{tabular}

Note: Form means the spoken words or consecratory payers, matter means the quiddity of the sacrament.

\section{Authority to change the selectivity of priesthood}

Priesthood's proper end is the Eucharistic celebration. From this sacramental conjunction and perhaps because Jesus instituted the Eucharist, the Church has argued a male priest represents Christ-male best. By implication, the Church has rejected the consideration of a female presbyterate (see Table 1). These stances translate into a three-fold issue of meninstitutionalized authority: (a) denying that women be admitted to the ministerial priesthood, (b) belying women's co-celebrant presence at the Last Supper, and (c) denying to have authority to change or to make new interpretations on the subject. The insistence of celibacy eventually led to the denial of admission of women into holy orders. The Church made statements to end this dialogue regarding the admission of women into the priesthood in the past century (see Inter insigniores, 1976, and Ordenatio sacerdotalis, 1994). The first statement came from the Congregation for the Evangelization of Peoples, formerly known as the Congregation for the Propagation of the Faith, and the Inquisition. The second came from the pope in the form an encyclical letter. Both documents, however, lacked dogmatic status and 
remain as positional statements. What is interesting is the papal encyclical claimed the Church has no authority to chance the selectivity of men priests. But this letter contradicts the congregational document that sustained: "it is the church's Magisterium who has the authority to decide what can change and what can remain immutable in various domains such as the admission of women to the priesthood" [my emphasis] (Beauchesne, 1995, p. 2). More specifically, Inter insigniores (1976) indicated:

This was already the teaching of the council of Trent, which declared: "In the Church there has always existed this power, that in the administration of the sacraments, provided that their substance remains unaltered, she can lay down or modify what she considers more fitting either for the benefit of those who receive them or for respect towards those same sacraments, according to varying circumstances, times or places (Inter insigniores 14. Session 21, chap. 2).

On the one hand, the Church denies having the authority to make changes on the selectivity of priesthood. But priesthood's essence is the Eucharist, not the person of the presider. The presider is the instrumental matter of the sacrament. On the other hand, the Church claims authority to make fundamental changes about the administration of sacraments. And this is precisely the function of the presider. There is no reason to perpetuate this duplicity in perspectives about changes to the instrument or to the matter of the priesthood. Opposing female ordination only leads to the consideration of another aspect of priesthood's sacramental constituency: The identical representation of Jesus at the altar by a male priest.

There cannot be an identical representation of Jesus' personhood by any human person. To resolve this, Thomas Aquinas (1224 - $1275 \mathrm{CE}$ ) assigned instrumental causality to the priestly role. In this sense, the priest is only an instrument of Jesus at the altar. Aquinas' instrumental causality deconstructs the preference for men-males to represent Jesus because any human agent is ontologically distinct from the One signified, and humanity includes both males and females (Ferrara, 1994a). To be fair, any priest is only human, and Jesus is both divine and human fully. Further, the validity of priestly representation rests on humanity because the human instrument shares the same species Jesus chose to embody. Even though Jesus was male, he also was the God-man and no human whether male or female can fully represent this two-natured personhood. Nevertheless, the togetherness of male and female represent the divinity of Jesus because humans were made to resemble the divine as complementary sexed beings, in the likeness of their source. This brings clarity to the story in Genesis 1:27. Furthermore, the axiom in persona Christi is not a valid justification to argue for only men to represent Jesus, or Jesus' maleness (Ferrara, 1994a, 1994b).

Moreover, the words of Eucharistic consecration are Jesus' words, not the priest's words (Ferrara, 1994b). Hence, sexuality has nothing to do with being able to exercise instrumental causality of a human-benefiting act Jesus instituted (Ratzinger, 1994). The priest's instrumental action is "only equal to quoting Jesus in pronouncing the words of consecration [my emphasis] and such instrumental capacity of quoting by an ordained priest has nothing to do with the priest being a man" (Ferrara, 1994a, p. 211) Rather, the sacerdotal function is successful insofar as the priest is a human person who shares in the humanity of Jesus, just as women share in the humanity of Jesus.

\section{Proper Matter for Ordination}

The creatural condition of humanity is naturally good (Gen. 1: 31; Eccl. 3: 11; Tim. 4: 4). God designed and made humanity sexually in literal terms. The human sexes were intrinsic to the divine design and to the divine image (Gen. 1:26). Thus, humanity could not be complete 
without sexuality. And the goodness and completeness of humanity enticed its Creator to share in it completely and without reservations in the sexed flesh of Jesus (Jn. 1:14).

The God-man, Jesus, was fully human and did not hold on to his divinity to live as a member of the Homo sapiens species (Phil. 2:6; 2 Cor. 8:9). But God's incarnation was not invasive or capricious, rather it offered deference to the sexuality of Mary and respected her willingness to co-participate in God's plan (Lk. 1:38). Thus, to become human, God used the human female as a co-participatory instrument of God's self-expression in Jesus' humanity. Mary was the gate through which the numinous and the human became effectively one. Mary and her willingness to bear Jesus to humanity is what made possible the priesthood of God. The human female sex enabled God to redeem humanity in a complete sense. Without a woman, and without sharing in this woman's flesh, and blood, and chromosomal makeup, the organic existence of Jesus would have never been accomplished. By taking on human flesh, Jesus also raised humanity to a familial encounter with God (Jn. 1:14; Jn. 10:10). No longer would humanity simply remain as creatures of the Creator, but as sons and daughters of the Father (Matt. 6: 6, Matt. 6:9). Jesus' humanity is what made effective his sacrifice on the cross. And the redeeming intent of God was made possible insofar as Jesus was fully human. The quiddity or whatness of Jesus was his humanity.

Jesus' humanity also became the cornerstone of God's own salvific edifice (Jn. 2:9). His selfoffering on the altar of the cross replaced all animal and human sacrifices humans had practiced to appease and to worship the numinous. These ancient sacrifices did not transform the human heart in ways the Eucharist would accomplish. Jesus offered his fleshed humanity fully and without reservations upon the cross. His role as a sacrificer replaced the ancient priesthood and granted him a supreme status as priest of the New Covenant (Heb. 4: 14-16). He chose to die for his friends and fellow humans (Jn. 15:13). But this was possible only insofar as he was also human.

Most important, Jesus' humanity raised humanity to the eligibility of sacramental grace (Jn. 14:6). Human nature became the out of which sacraments came to be. Humanity was the whatness (matter) of the sacraments. Human beings beyond phenotypic distinctions and beyond gendered corporealities became the beneficiaries of God's redemption in the sacramental life of the Church (Eph. 1:4). Humanity in all its sexual manifestations is the proper matter for the sacramental life that Jesus established.

God's design of the human condition is complete insofar as it includes sexuality. Sexuality enables the human species to be co-participants with God in the transmission of life (Gen. 1:28). Co-participation of the sexes makes possible the transmission of human life. In this sense, sexuality is the matter (whatness) and the efficiency of humanity. All gendered expressions of sexuality are crucial to nurture new life. Thus, human sexuality completes God's design of human nature. But human sexuality comprises all its manifestations for it to be telically fruitful.

Human sexuality is communal, as God is communal in the trinity that Jesus revealed (Matt. $5: 48)$. In a similar sense, the intimate communion of male and female are expressive of God's communion (Gen. 1:27). This unity of sexes provides humans with a taste of God that is tangible and extremely subjective, but it is also transformative (Song of sg. 6:3). The communion of human sexes has the power to transform human persons in perceptible ways. This is what makes sexuality theologically meaningful: The self-donation of the persons has the power to transform and to edify those who are intimate and genuine in their search for unity. 
Human sexuality is the proper matter and the purposive end of the human condition. It makes the bodily existence of each person meaningful. In this sense, sexuality is inclusive of genders. And Jesus' humanity exalts human sexuality in inclusive terms. That is to say, by taking on flesh and living the human condition, Jesus perfected humanity (male and female) in metaphysical terms (Jn. 1:14). By implication, the very purpose of human existence is sexual, and Jesus' humanity does not exclude persons in terms of gender. Jesus' humanity includes women (Mk. 15:40; Matt. 27: 55-56; Kopas, 1986; Platt, 1977). Instead, Jesus' human person as a fully sexual being also elevates all sexes and his intentional attempts to bring balance to sexual transactions through his ministry further evince his acceptance of sexual complementarity.

Aristotle's four causes of nature are useful to identify the elements of sacraments (Apostle, 1980), as displayed in Table 2.

(1) Matter is the whatness out of which something is made or comes to be. Matter is the first metaphysical cause that objectifies the natural order. The supreme priesthood of Jesus depends on his humanity aided by his divinity and by Mary's assent. As such, the out of which the new priesthood came to be is the humanity of Jesus. His humanity is the proper matter (whatness) of priesthood. Certainly, no human person can fully represent the God-man, Jesus, at the altar, except for the fact that every person is able to stand in his place by virtue of sharing in the same flesh, and the same species.

(2) Form is the account of what a specific something is to be. The form of Jesus' priesthood is the redemption of humanity and the revelation of the Spirit. He made this explicit in the words of institution of the Eucharist (Matt. 26:26; Mk. 14:22; 1 Cor. 11:24).

(3) Efficiency is the source of the change that enables something to come into being. Not only was it God's will that made Jesus' humanity possible in human history, but it also was the choice Jesus made to self-emptying himself of his divinity to achieve complete humanity. This specific efficiency of the incarnation came from the Spirit's intervention (Lk. 1:35). This efficiency causality also included Mary's choice to deliver Jesus to humanity through her pregnancy (Lk. 1:38).

(4) Finality is the purpose for which something exists at all. Jesus was not only human but also fully sexual. His existence was a manifestation of God's perfection and love. God saw fit to share in our humanity, and God created humanity in God's likeness, male and female beings. The taking on sexed flesh conveys the importance of sexed humanity in the person of Jesus. The purpose of this encounter was to make humanity holy.

Further causality of sacramental elements as displayed in Table 2 may be illustrated by considering at least two sacraments: Baptism and Sacred Orders (priesthood). The purpose of baptism is the inclusion of the recipient into the divine life via a cleansing. The matter of baptism is a liquid substance such as water, or even saliva. For example, Jesuit missionaries adjusted to their circumstances and used saliva to baptize American Indians in the colonial period (for a pictorial depiction watch "Black Robe," Milliken \& Beresford, 1991). The proper minister of baptism is traditionally ordained cleric (whether a bishop, a presbyter, or a deacon) but by sufficiency, it is a human person able to act as God's instrument even if this person were not baptized. The proper recipient of baptism is also a human being. The baptismal form is the words: "I baptize you in the name ... " And, the agent that created this sacrament is God in the person of Jesus. 
In terms of Sacred Orders or priesthood, its purpose is to offer sacrifice of atonement for self and for the immediate community, and to deliver Jesus to humanity. Hence, the celebration of the Eucharist is the proper end of this sacrament. The matter of priesthood is its own sacramental signification in the person of the celebrating minister (Butler, 1995). The minister is also God's instrument that lends the human self for God to accomplish God's sanctifying action in benefit of the human realm. This is made explicit in the consecratory texts: This sacrifice is offered for God's human family from East to West without discrimination based on national origin, race, belief, or gender, including those who are not baptized or who are unaware of God's existence.

Jesus' intent was to foster individual faith and a personal relationship with God (Thom, 2009). When we speak of the proper matter of priesthood, we are referring to the human person via whom God is able to reach the human realm effectively. Moreover, priesthood is not conferred on any other living being whether a plant or an animal deprived of a rational, sexual soul. That is, dogs are not ordained for ministering to humans, neither are trees nor rocks; but only human beings who share with Jesus in the human species. By implication, to argue for gender distinctions to justify an all men celibate priesthood begs the question of God's original intent (Beauchesne, 1995; Philibert, 2000; Yokarinis, 2002). It follows that the proper matter for this sacrament is the human person such as a liquid substance is the proper matter for baptism. This position allows for the ordination of homosexual men, bisexual men, and women to an inclusive priesthood. Furthermore, in the humanity of Jesus there are neither male nor female (Gal. 3:28) distinctions that support only men preferences for the priesthood of the New Covenant.

Divine revelation is the daily and personal communication between the Spirit of God and each of us (Paul VI, 1965). Divine revelation belongs to everyone, and everyone makes up the Church. Divine revelation is not only available to the hierarchy. It is available to everyone who either kneels, or walks, or reflects deeply about life and makes the best choices given their respective contexts. This process brings about every person's fullest potential. Perhaps the hierarchy of the Church ought to embrace humbly what Paul VI wrote (1965) about divine revelation. This stance would make manifest God's redeeming love in 21st century societies, and it would help us to reconsider what it means to be called to serve as priests including women into the priesthood of Jesus.

\section{IMPLICATIONS}

Good theology leads to tangible experiences of what is not experienceable. This happens through faith that is transforming, not to make-believe what is not real, but to accept what is real yet imperceptible. Reason aids this process. The theological value of each human person is too profound to be denied. It is the expression of the creative love of a God whose creative nature is precisely to bring into existence each of us. Each human person is a complete unity of soul-body-organic-sexuality. Our sexuality completes our humanity. And it makes possible the manifestation of distinctive aspects of our humanity: to choose among alternatives, to make sense of life, to be transformed through learning, and to seek for unity with another, and with the numinous.

Our gendered corporealities have as primary purpose the preservation of our species, but the primary purpose of our sexual identities is to express each of us in communion with another in intimacy. Sexuality makes possible the communicability of the human self. Our sexual communion awakens our proclivity to seek for what is transcendental and divine. Put differently, our sexualities' primary purpose is to lead us to intimate communion with another, in the same manner in which God is communion. 
Over the centuries, we have come to accept the revelation of the Creator of everything that is visible and invisible in the person of Jesus. Jesus joined our nature completely to establish an intimacy with each of us and to enable us to worship his Father through true sacerdotal activity. This priestly agency must not be limited by sexuality or gender-like preferences. If we are to emulate Jesus' gender-like preferences, we should then engage women intentionally and we would entrust women to transmit their sense of God to others.

Much of what we claim to know about God comes from male interpretations. We need to understand God from female interpretations. Ordaining women into the priesthood is not simply an aspect of social justice, or an inchoate proposition, but an understanding that in God there is maleness and femaleness, and no division between the sexes. We must end the prejudice the Church hierarchy has practiced against women for over two millennia, no matter how eloquent reflections they use to masquerade their preferences.

Women in ministry have much to contribute to our liturgical celebrations and to our understanding of life's vicissitudes and blessings. Ordaining women to ministry would also augment opportunities to establish the kingdom of God on this planet because their ministries would expand social development in ways unknown to us presently. Ordaining women would also provide them with vocational satisfaction, especially because some women sincerely claim to have been called by God to minister as priestesses. This vocational satisfaction is at the heart of a lifestyle dedicated to preach the good news and offer the sacraments to others. The selfefficacy and dignity that would ensue from ministering to others would be similar to being successful in a profession that is focused on meeting the spiritual needs of people without distinction. Who are we to say God is not calling many women to the priesthood?

\section{References}

Allen, P. (1985). The concept of woman: The Aristotelian revolution, 750 BC - 1250 AD. Grand Rapids, MI: Wm. B. Eerdmans Publishing Co.

Apostle, H. G. (1980). Aristotle’s physics. Grinnell, IA: Peripatetic Press.

Armstrong, K. (2001). Buddha. New York: Penguin Group.

Aristotle. (1996). Aristotle: Introductory readings.

(T. Irwin, \& G. Fine, Trans.). Indianapolis, IN: Hackett Publishing Company, Inc.

Aslan, R. (2013). Zealot: The life and times of Jesus of Nazareth. New York: Random House, Inc.

Barrat, A. (2006). What is ordination? A Roman Catholic perspective. Ecclesiology, 3, 57-79. doi: $10.1177 / 1744136606067682$

Beauchesne, R. J. (1995). Explorations and responses: Scriptural/theological argument against women's ordination (simply stated) and responses. Journal of Ecumenical Studies, 32, 107-113.

Benagiano, G., \& Mori, M. (2007). Evolution of thinking of the Catholic Church on the beginning of human life. Ethics, Law and Moral Philosophy of Reproductive Biomedicine, 2, 162-268.

Blauner, B. (1991). Gay priests [Review of the book Gay Priests, by J. G. Wolf (Ed.)]. American Journal of Sociology, 96, 1602-1603. doi:10.1086/229730

Butler, S. (1995). Quaestio Disputata: "In persona Christi." Theological Studies, 56, 61-80.

Chadwick, H. (1993). The early church. New York: Penguin Group.

Cohn, H. (1963). The trial and death of Jesus. Old Saybrook, CT: Konecky \& Konecky.

Driver, T. (1965). Sexuality and Jesus. Union Seminary Quarterly Review, 20, 243-250. 
Del Rio, C. M. (2012). Freedom of conscience is freedom of choice: Women's reproductive needs, rights, and their therapeutic implications. Advances in Applied Sociology, 2, 214-222. doi:10.4236/aasoci.2012.23028

Duran, K. (1993). Homosexuality and Islam. In A. Swidler (Ed.), Homosexuality and world religions (pp. 181 198). Valley Forge, PA: Trinity Press International.

Ferrara, D. M. (1994a). Note. The ordination of women: Tradition and meaning. Theological Studies, 55, 706-719.

Ferrara, D. M. (1994b). Representation or self-effacement? The axiom in persona Christi in St. Thomas and the magisterium. Theological Studies, 55, 195-224.

Fisher, T. D., Moore, Z. T., \& Pittenger, M. J. (2012).

Sex on the brain? An examination of frequency of sexual cognitions as a function of gender, erotophilia, and social desirability. Journal of Sex Research, 43, 69-77. doi: 10.1080/00224499.2011.565429

Girzone, J. (1994). Never alone. New York: Random House, Inc.

Greeley, A. M. (2007). Jesus: A meditation on his stories and his relationships with women. New York: A Tom Doherty Associates Book.

Greeley, A. M. (2004). Priests: A calling in crisis.

Chicago: The University of Chicago Press.

Hoenkamp-Bisschops, A.M. (1992). Catholic priests and their experience of celibacy. Journal of Religion and Health, 31, 327-336.

Heid, S. (2001). Celibacy in the early Church: The beginnings of obligatory continence for clerics in East and West. San Francisco: Ignatius Press.

Inter Insigniores (1976). Declaration on the question of admission of women to the ministerial priesthood. Sacred Congregation for the Doctrine of the Faith. Retrieved from http://www.papalenciclicals.net/Paul06/piteri.htm

Irvine, J. M. (1990). Disorders of desire: Sex and gender in modern American sexology. Philadelphia: Temple University Press.

James, W. (1958). The varieties of religious experience. New York: The New American Library of World Literature, Inc.

Kelly-Zukowski, M. (2005). The Catholic Church's restrictions on female participation and some biblical responses. Gender Issues, Fall 2005, 43-55.

Kopas, J. (1986). Jesus and women: Luke's gospel.

Theology Today, 43, 192-202. doi: 10.1177/004057368604300205

Lorber, J. (1994). Paradoxes of gender. Binghampton,

New York: Vail-Ballou Press.

Laborem Exercens. (1981). On Human work. Retrieved from http://w2.vatican.va/content/john-paulii/en/encyclicals/documents/hf_jp-ii_enc_14091981_laborem-exercens.html

Maccoby, H. (1986). The mythmaker: Paul and the invention of Christianity. San Francisco: Harper Collins Publishers, Inc.

Mann, C. C. (2011). The birth of religion: The world's first temple. Göbekli Tepe, Turkey circa 9600 BC. National Geographic, June 2011, 219 (6), 34-59.

McDowell, M. G. (2013). The iconicity of priesthood: Male bodies or embodied virtue? Studies in Christian Ethics, 1-14. doi: 10.1177/0953946813484412

Milliken, S. (Producer), \& Beresford, B. (Director). (1991). Black robe [Motion Picture]. Australia; Canada: Alliance Communications, Samson Productions.

Murphy, N. (1998). Human nature: Historical, scientific, and religious issues. In W. Brown, N. Murphy, \& H. Newton Malloy (Eds.) Whatever happened to the soul? Minneapolis: Fortress.

Nichols, T. (2010). Death and afterlife: A theological introduction. Grand Rapids, MI: Brazos Press.

O’Brien, J. (2009). Encyclopedia of gender and society. Thousand Oaks, CA: SAGE Publications, Inc. 
O’Brien, J., \& Major, W. (1982). In the beginning: Creation myths from ancient Mesopotamia, Israel, and Greece. The American Academy of Religion.

O’Malley, J. W. (2013). What happened an the council.

Cambridge, MA: The Belknap Press of Harvard University Press.

Ordenatio Sacerdotalis (1994). Apostolic letter of John Paul II to the bishops of the Catholic church on reserving priestly ordination to men alone. Libreria Editrice Vaticana. Retrieved from

http://www.vatican.va/holy_father/john_paul_ii/apost_letters/documents/hf_jpiii_apl_22051994_ordinatiosacerdotalis_en.html

Pietkiewicz, I. J., Bachryj, D. (2014). Help-Seeking Attitudes and Coping Strategies Among Roman Catholic Secular Clergy. Psychology of Religion and Spirituality, Dec 1 , 2014, No Pagination Specified.

http://dx.doi.org/10.1037/rel0000019

Paris, J. W. (2011). The end of sexual identity: Why sex is too important to define who we are. Downers Grove, IL: InterVarsity Press.

Paul VI. (1965). Dei Verbum. Retrieved from:

http://www.vatican.va/archive/hist_councils/ii_vatican_council/documents/vat-ii_const_19651118_deiverbum_en.html

Philibert, P. (2000). Issues for a theology of priesthood: A status report. In D. Goergen and Ann Garrido (Eds.), The theology of priesthood (pp. 1-41). Collegeville, MN: Liturgical Press.

Phipps, W. E. (1996). The sexuality of Jesus.

Cleveland, OH: The Pilgrim Press.

Platt, E. E. (1977). The ministry of Mary of Bethany.

Theology Today, 34, 29-39. doi: 10.1177/004057367703400104

Reumann, J. (1966). Jesus in the Church's gospels:

Modern scholarship and the earliest sources. Philadelphia, PA: Fortress Press.

Ratzinger, J. (1994). Catechism of the Catholic Church

(1st. Ed.). Cittá del Vaticano: Libreria Editrice Vaticana.

Rerum Novarum. On capital and labor. Encyclical of pope Leo XIII. May 15, 1891. Retrieved from http://www.papalencyclicals.net/Leo13/l13rerum.htm

Steinfels, P. (2003). A people adrift: The crisis of the Roman Catholic Church in America. New York: Simon \& Schuster.

Stoller, R. J. (1985). Presentations of gender. New Haven: Yale University Press.

Tchilingirian, H. (1996). The Armenian apostolic orthodox. Retrieved from

http://www.sain.org/American.Church/intro.txt

The Holy Bible: New International Version. (3rd. Ed.).

(1984). Colorado Springs, CO: International Bible Society.

Thiemann, R. F. (1987). The unnamed woman at Bethany.

Theology Today, 44, 179-188. doi: 10.1177/004057368704400205

Thom, J. C. (2009). Justice in the sermon of the mount: An Aristotelian reading. Novum Testamentum, 51, 314-338. doi: 10.1163/156853609X432792

Turcescu, L. (1996). Eastern orthodox reactions to the ministry section of the Lima document. Journal of Ecumenical Studies, 33, 330-343.

Untent, K. (1991). Forum: The ordination of women: Can the horizons widen? Worship, 65, 50-59. 
Wallace, R. A. (1991). The 1990 H. Paul Douglass Lecture: Women administrators of priestless parishes: Constrains and opportunities. Review of Religion Research, 32(4), 289-304

Wigmore, B. (1996). The sins of the fathers: Adopted Irish children have no right to know who their birth parents are. It is a painful anomaly for which the Catholic church bears large responsibility. New Statesman, 135(4304), 20-22

Yokarinis, C. (2002). A Patristic basis for a theological anthropology of women in their distinctive humanity. Anglican Theological Review, 84, 585-608. ACCESSION \# 74 